\title{
PENGARUH MODEL PEMBELAJARAN PROBLEM BASED LEARNING BERBANTUAN INFORMATION AND COMMUNICATION TECHNOLOGIES TERHADAP KETERAMPILAN BERPIKIR KRITIS SISWA
}

\author{
I.A.P.Febby Wulandari, N.M.Pujani, P.Prima Juniartina \\ Program Studi S1 Pendidikan IPA \\ Universitas Pendidikan Ganesha \\ Singaraja, Indonesia
}

Email: \{putu.febby.wulandari, made.pujani, prima.juniartina\}@undiksha.ac.id

\begin{abstract}
Abstrak
Penelitian ini bertujuan mendeskripsikan perbedaan keterampilan berpikir kritis antara siswa yang dibelajarkan dengan model Problem Based Learning (PBL) berbantuan Information and Communication Technologies (ICT) dan siswa yang dibelajarkan dengan model Direct Instruction (DI). Penelitian ini termasuk penelitian eksperimen semu dengan rancangan Nonequivalen Pretest-Posttest Control Group Design. Populasi dalam penelitian ini adalah seluruh siswa kelas VII SMP N 1 Sukasada pada semester genap tahun ajaran 2018/2019 yang berjumlah 234 siswa. Sampel penelitian dipilih dengan teknik cluster random sampling. Didapatkan sebanyak dua kelas yaitu kelas VII F sebagai kelas eksperimen diterapkan model PBL berbantuan ICT dan kelas VII G sebagai kelas kontrol diterapkan model DI dengan jumlah 75 siswa. Data keterampilan berpikir kritis siswa diperoleh dengan metode tes bentuk uraian dengan jumlah 15 butir soal. Data keterampilan berpikir kritis dianalisis secara deskriptif dan menggunakan uji Anakova dengan taraf signifikan 5\%. Hasil penelitian menemukan bahwa: (1) Peningkatan keterampilan berpikir kritis siswa yang belajar dengan model PBL berbantuan ICT peningkatannya berkualifikasi sedang ( $N$ gain $=0,69)$. Peningkatan Ketercapaian dimensi merumuskan masalah, memberikan argument, melakukan induksi, melakukan deduksi, melakukan evaluasi dan dimensi memutuskan dan melaksanakannya semuanya berkualifikasi sedang. (2) Terdapat perbedaan keterampilan berpikir kritis siswa antara siswa yang belajar dengan model PBL bebantuan ICT dan model pembelajaran DI. Hal tersebut ditunjukkan oleh skor rata-rata posttest kelompok yang dibelajarkan dengan model PBL berbantuan ICT yaitu sebesar 77,33 sedangkan kelompok yang dibelajarkan dengan model DI yaitu sebesar 71,60 .
\end{abstract}

Kata kunci: Model pembelajaran problem based learning, model pembelajaran direct instruction, keterampilan berpikir kritis

\begin{abstract}
This study aims to described the differences critical thinking skills students of problem based learning (PBL) model assisted Information and Communication Technologies (ICT) with direct instruction (DI) model. This research was quasi experimental research with nonequivalent pretest-posttest control group design. The population in this research were all students of VII grade of SMP Negeri 1 Sukasada on 2018/2019 academic year, amounting 234 students. The sample of the research were 75 students which was determined by simple random sampling technique which consisted of two classes, namely VIIF class as the experimental group which were taught through PBL model assisted ICT and VIIG class as the control group which were taught through DI model. The instrument used in this research is the critical critical thinking skill test. The data of this research was analyzed descriptively by using Anacova significant level $5 \%$. The results show that: (1) critical thinking skills student with model PBL assisted ICT have a medium qualified ( $\mathrm{N}$-Gain=0,69). Achievement of the dimensions of formulating the problem, giving arguments, induction, deduction, performing evaluation and the dimensions of deciding and implementing medium qualified. (2) There is a difference of critical thinking skill between students learning with learning PBL model assisted ICT and DI model. This indicated by the posttest mean score of each class 77,33 and 71,60 .
\end{abstract}

Keywords: problem based learning model, direct instruction model, critical thinking skill. 


\section{PENDAHULUAN}

Pendidikan merupakan sarana yang kongkret yang biasa digunakan untuk mengembangkan pengetahuan bangsa dan warga negaranya. Menuurt UU No 20 Tahun 2003 tentang Sistem Pendidikan Nasional menyatakan bahwa pendidikan adalah usaha sadar dan terencana untuk siswa secara aktif mengembangkan potensi dirinya untuk memiliki kekuatan spiritual keagamaan, pengendalian diri, kepribadian, kecerdasan, akhlak mulia, serta memiliki keterampilan yang diperlukan untuk dirinya, masyarakat bangsa dan negara (UU RI No 20 Tahun 2003).

Berbagai upaya telah dilakukan peemerintah dalam meningkatkan mutu pendidikan, slaah satu perubahan yang dilakukan oleh pemerintah untuk mencapai keberhasilan tujuan pendidikan adalah dengan melakukan perubahan pada kurikulum. Perubahan yang terjadi adalah pergantian Kurikulum 2013 dari kurikulum sebelumnya yaitu Kurikulum KTSP (Niron,2016).

Proses pembelajaran pada Kurikulum 2013 untuk semua jenjang dilaksanakan menggunakan pendekatan saintifik. Proses pembelajaran saintifik menyentuh tiga ranah pembelajaran, yaitu sikap, pengetahuan, dan keterampilan. Pendekatan saintifik (scientific approach) dalam pembelajaran sebagaimana dimaksud meliputi tentang $5 \mathrm{M}$ yaitu terdiri dari mengamati, menanya, mencoba, mengolah, dan mengkomunikasikan untuk semua mata pelajaran. Jika dilihat secara mata pelajaran, materi, atau situasi tertentu, sangat mungkin pendekatan ilmiah ini tidak selalu tepat diaplikasikan secara prosedural. Pada kondisi seperti ini tentu saja proses pembelajaran harus tetap menerapkan nilai-nilai atau sifat-sifat ilmiah serta menghindari nilai-nilai atau sifat-sifat non-ilmiah (Setiawan, 2017).

Upaya yang dilakukan pemerintah seyogyanya dapat memberikan pengaruh yang positif terhadap kualitas pendidikan di Indonesia. Hal tersebut telihat $\mathrm{Hal}$ tersebut terlihat dari hasil Program for International Student Assessment (PISA) tahun 2015, Indonesia menduduki peringkat 10 terbawah dari 69 negara yang berpartisipasi, dengan rincian, 1) prestasi literasi membaca siswa Indonesia menduduki peringkat 61 dari 69 negara, 2) prestasi literasi Sains/PA siswa Indonesia menduduki peringkat 62 dari 69 negara, dan 3) prestasi literasi Matematika siswa Indonesia menduduki peringkat 63 dari 69 negara yang berpartisipasi (Iswandi, 2016). Hal serupa juga terlihat dari hasil Trend in International Mathematics and Science Study (TIMSS) tahun 2015, Indonesia berada pada ranking 36 dari 49 negara yang berpartisipasi (Sarnapi, 2016).

Berdasarkan hasil penelitian yang telah dilakukan oleh Fuad et al. (2017) melalui penelitiannya yang menunjukkan bahwa kemampuan berpikir kritis peserta didik pada jenjang SMP yang ada di kediri masih dalam kategori rendah. Terbukti dari rata-rata skor yang diperolehnya dalam tes berpikir kritis siswa yaitu dengan skor 21,89 dari skala 0-100. Peneliti lain juga melalukakan penelitian yang berkaitan dengan kemampuan berpikir kritis siswa yaitu penelitian oleh Nuryanti et al. (2018) yang menyatakan bahwa kemampuan berpikir kritis siswa SMP Negeri 1 Delanggu Kabupaten Klaten tergolong rendah. Hal ini dibuktikan dengan persentase rata-rata kategori B (baik) yang hanya 40,46\%. Hal ini sejalan dengan penelitian yang dilakukan oleh Prihartiningsih dkk. (2016); Martawijaya (2015) dan Normaya (2015) yang menyatakan bahwa kemampuan berpikir kritis siswa SMP masih belum berkembang atau masih rendah. Rendahnya kemampuan berpikir kritis siswa ini antara lain dikarenakan pembelajaran yang diterapkan di sekolah masih didominasi oleh guru sehingga kurang melatih kemampuan berpikir kritis pada siswa. Hal ini sejalan dengan penelitian Patonah (2014) yang mengungkapkan bahwa pembelajaran IPA di sekolah masih banyak didominasi oleh peran guru sehingga kadang dapat menghambat kemampuan siswa untuk berpikir kritis. Fakta yang dipelajari di bangku sekolah sering tidak berkaitan dengan apa yang dialami atau yang terdapat di lingkungan siswa bahkan kadang bertolak belakang. Kondisi semacam ini dapat menggiring pada lemahnya siswa untuk menalar, mereka lebih senang menghafal apa yang diperoleh 
dari guru daripada mengembangkan daya berpikir kritisnya. Pada gilirannya siswa memiliki kelemahan untuk menyampaiakan pendapatnya sendiri dan lemah dalam menganalisis serta mudah bergantung pada orang lain dibandingkan bertanggung jawab terhadap pilihannya.

Retnosari et al., 2016 menyatakan bahwa rendahnya keterampilan berpikir kritis siswa disebabkan oleh keterampilan berpikir kritis awal siswa, yang dilihat dari hasil analisis menunjukkan bahwa hampir keseluruhan siswa $(75,82 \%)$ mempunyai keterampilan berpikir kritis awal siswa masih kurang atau rendah. Idealnya proses pembelajaran di sekolah perlu menggali pengetahuan awal yang dimiliki oleh siswa, karena pengetahuan awal memiliki pengaruh terhadap pengembangan keterampilan berpikir kritis yang lebih optimal. Pengetahuan awal merupakan pengetahuan atau pengalaman sebelumnya yang dimiliki oleh individu, pengetahuan ini menjadi modal bagi individu untuk mencapai pengetahuan baru atau memecahkan permasalahan yang sejenis atau permasalahan yang baru ditemui. Individu yang mempunyai pengetahuan awal yang baik dapat memperoleh pengetahuan baru yang baik pula, dan sebaliknya. Dengan begitu untuk mengoptimalkan kemampuan berpikir yang logis maka pengetahuan awal harus sudah dimiliki terlebih dahulu oleh individu (Pamungkas,2017).

Berdasarkan data dan fakta yang sudah diuraikan sebelumnya dapat dikatakan bahwa keterampilan berpikir kritis siswa masih rendah. Sejumlah faktor yang dapat mempengaruhi keterampilan berpikir kritis siswa adalah faktor internal dan faktor eksternal. Faktor internal yang dapat mempengaruhi seperti tingkat berpikir, keaktifan, gaya belajar, minat, bakat dan motivasi siswa yang masih kurang, sedangkan untuk faktor eksternal adalah peran guru. Peran guru yang dapat mempengaruhi keterampilan berpikir kritis siswa dapat disebabkan karena penerapan model pembelajaran yang kurang tepat. Model pembelajaran yang sering diterapkan oleh guru adalah model pembelajaran langsung (Direct Instruction). Model pembelajaran langsung adalah model pembelajaran yang berpusat pada guru, sehingga dalam proses pembelajaran lebih didominasi oleh guru. Permasalahan lain selain model pembelajaran yang kurang tepat dipilih oleh guru adalah guru masih kurang dalam menggunakan dan memilih media pembelajaran yang tepat untuk digunakan. Secara umum kegiatan dalam model pembelajaran langsung terdiri dari 5 tahapan dalam pelaksanaan pembelajaran, yaitu:1) menyampaikan tujuan dan kompetensi, 2) mendemonstrasikan pengetahuan, 3) membimbing pelatihan, 4) mengecek pemahaman dan memberi umpan balik, dan 5) pelatihan lanjutan dan penerapan (Kardi \& Nur, 2000). Penerapan model pembelajaran langsung dalam pembelajaran IPA di kelas kurang efektif dalam meningkatkan pemahaman konsep siswa.

Solusi untuk memecahkan permasalahan terkait dengan keterampilan berpikir kritis siswa adalah dengan penerapan model pembelajaran yang tepat untuk mengembangkan keterampilan berpikir kritis. Pembelajaran yang berpijak pada pengembangan keterampilan berpikir kritis dinilai dari mampu menghasilkan learning output yang berkualitas. Model pembelajaran adalah suatu prosedur sistematis dalam mengorganisasikan pengalaman belajar untuk mencapai tujuan belajar. Dapat juga diartikan sebagai suatu pendekatan yang digunakan dalam kegiatan pembelajaran. Sebagai seorang guru harus mampu memilih model pembelajaran yang tepat bagi peserta didik. Salah satu model yang sesuai adalah model pembelajaran berbasis masalah (Problem Based Learning/PBL). Dalam pelaksanaan pembelajaran, siswa dituntun terlibat aktif dalam mengikuti proses pembelajaran melalui diskusi kelompok. Langkah awal kegiatan pembelajaran dilaksanakan dengan mengajak siswa untuk memahami situasi yang diajukan baik oleh guru maupun siswa, yang dimulai dari apa yang telah diketahui oleh siswa (Rusman, 2012). Secara umum kegiatan dalam model PBL ini memiliki 5 langkah pembelajaran yaitu: 1) starting a new class, 2) starting new problem, 3) problem follow up, 4) perfomance presentation 5) after 
conclusion of problem (Barrow and Myers, 1993).

Permasalahan yang disajikan dalam model PBL ini dapat berupa fenomena yang mungkin dialami oleh siswa dalam kehidupan sehari-hari atau dalam dunia nyata yang dapat disajikan oleh guru melalui animasi/simulasi, video yang memudahkan siswa dalam menjelaskan permasalahan pada fenomena tersebut. Hal ini dapat menjadikan proses pembelajaran dengan model $\mathrm{PBL}$ yang divariasikan dengan sebuah video, gambar, animasi/simulasi yang dapat menciptakan suasana pembelajaran yang lebih menarik dan siswa menjadi lebih semangat dan tidak cepat mengantuk atau bosan ketika proses pembelajaran IPA di dalam kelas. Berdasarkan hal tersebut, maka perlu dikembangkan suatu model pembelajaran yang disertai dengan bantuan ICT. Selain model pembelajaran yang efektif, dalam proses pembelajaran juga dibutuhkan media pembelajaran yang mendukung.

Model pembelajaran berbantuan media TIK dimaksudkan oleh Sendag dan Odabasi (dalam Nirbita, 2018) sebagai cara untuk meningkatkan kemampuan berpikir siswa. Model ini menggunakan TIK sebagai perangkat lunak media berbasis aplikasi dalam proses pembelajaran. Dengan menggunakan metode ini, siswa dapat terlibat dalam pembelajaran proses sebagai subjek secara individu atau dalam kelompok. Guru sebagai fasilitator dapat memberikan aplikasi pendidikan video, bahan ajar, dan program evaluasi yang kemudian meningkatkan kemampuan siswa untuk berpikir kritis. Arsyad (2007) menyatakan bahwa peran komputer sebagai pembantu tambahan dalam belajar, pemanfaatannya meliputi penyajian informasi isi materi pelajaran, latihan, atau kedua-duanya. Modus ini dikenal sebagai Computer Assisted Instruction (CAI). CAI mendukung pembelajaran dan pelatihan akan tetapi bukanlah penyampaian utama materi pelajaran. Komputer dapat menyajikan informasi dan tahapan pembelajaran lainnya yang disampikan bukan dengan media komputer.

Menurut Sanjaya (2006) secara umum media merupakan kata jamak dari "medium" yang berarti perantara atau pengantar. Kata media berlaku untuk berbagai kegiatan atau usaha, seperti media dalam penyampaian pesan, media pengantar magnet atau panas dalam bidang Teknik. Istilah media digunakan juga dalam bidang pengajaran atau pendidikan sehingga istilahnya menjadi media pendidikan atau media pembelajaran. Ada beberapa konsep atau definisi media pendidikan atau media pembelajaran. Menurut Rossi dan Breidle (dalam Sanjaya, 2006:163) mengemukakan bahwa media pembelajaran adalah seluruh alat dan bahan yang dapat dipakai untuk mencapai tujuan pendidikan seperti radio, televisi, buku, koran, majalah dan sebagainya. Menurut Rossi alat-alat semacam radio dan televisi jika digunakan dan diprogram untuk pendidikan maka merupakan media pembelajaran. Namun demikian, media bukan hanya berupa alat atau bahan saja, akan tetapi hal-hal lain yang memungkinkan siswa dapat memperoleh pengetahuan. Proses pembelajaran di kelas akan lebih optimal apabila guru memilki kemampuan dalam menghubungkan model pembelajaran yang digunakan dengan media pembelajaran yang digunakan (ICT). Model pembelajaran yang dimaksud adalah Problem Based Learning (PBL) berbantuan ICT. Model PBL berbantuan ICT dalam penerapannya di kelas memiliki langkahlangkah pembelajaran yang sama dengan model PBL, hanya saja pada model PBL berbantuan ICT penyampaian masalahnya dapat berupa video, gambar, animasi atau simulasi yang ditampilkan di depan kelas dengan bantuan proyektor/LCD.

Berdasarkan uraian tersebut perlu dikaji lebih jauh mengenai pengaruh model problem based learning berbantuan ICT terhadap keterampilan berpikir kritis siswa. Tujuan yang ingin dicapai dalam penelitian ini adalah untuk mendeskripsikan perbedaan keterampilan berpikir kritis antara kelompok siswa yang dibelajarkan dengan model PBL berbantuan ICT dan model DI.

\section{METODE}

Penelitian ini adalah penelitian eksperimen semu dengan rancangan Nonequivalent Pretest-Posttest Control Group Design. Populasi dalam penelitian ini adalah seluruh kelas VII SMP $\mathrm{N} 1$ 
Sukasada pada semester genap tahun ajaran 2018/2019 yang berjumlah 234 siswa. Sampel penelitian dipilih dengan menggunakan teknik cluster random sampling. Sampel yang digunakan dalam penelitian berjumlah 75 siswa yang tersebar dalam 2 kelas, yaitu kelas eksperimen dan kelas kontrol. Metode pengumpulan data yang digunakan adalah dengan memberikan tes keterampilan berpikir kritis. Tes keterampilan berpikir kritis dalam bentuk uraian. Tes uraian dipilih dengan asumsi bahwa dengan menjawab tes uaraian, keterampilan berpikir kritis siswa lebih mudah diamati dibandingkan dengan menjawab tes objektif. Tes keterampilan berpikir kritis siswa dibuat mengacu pada 6 dimensi keterampilan berpikir kritis, yaitu merumuskan masalah, memberikan argument, melakukan deduksi, melakukan induksi, melakukan evaluasi serta memutuskan dan melaksanakannya. Instrumen pembelajaran berupa tes keterampilan berpikir kritis kemudian dilakukan uji coba instrumen dan diperoleh reliablitas yaitu 0,79 yang berkategori sedang dan dikatakan tes sudah reliabel. Sehingga dari hasil uji instrumen didapatkan 15 soal yang mewakili setiap dimensi keterampilan berpikir kritis yang digunakan.
Metode dan teknik analisis data yang digunakan dalam penelitian ini adalah dengan menggunakan statistik deskriptif dan statistik inferensial, untuk menguji hipotesis menggunakan ANAKOVA dengan taraf signifikansi 0,05.

\section{HASIL DAN PEMBAHASAN}

Data yang diperoleh pada penelitian ini adalah data kuantitatif, berupa skor pretest dan skor posttest keterampilan berpikir kritis siswa. Skor Pretest dan Posttest siswa untuk kelas eksperimen yang belajar dengan model PBL berbantuan ICT dan kelas kontrol yang belajar dengan model direct instruction (MDI) dapat dilihat berdasarkan analisis data tersebut diperoleh bahwa hasil pretest keterampilan berpikir kritis siswa pada kelompok MPBL berbantuan ICT berkisar antara 1,70 sampai dengan 55,0, dan kelompok MDI yang berkisar antara 1,70 sampai dengan 50,0 dengan skor minimum 0 dan skor maksimum 100. Hasil Posttest keterampilan berpikir kritis siswa pada kelompok MPBL berbantuan ICT berkisar antara 56,70 sampai dengan 96,70 dan kelompok MDI yang berkisar antara 50,00 sampai dengan 91,70 dengan skor minimumu 0 dan maksimal 100. Data yang diperoleh ditampilkan pada Tabel 1.

Tabel 1. Distribusi Frekuensi dan Presentase Nilai Pretest dan Posttest Keterampilan Berpikir Kritis Siswa

\begin{tabular}{|c|c|c|c|c|c|c|c|c|c|}
\hline \multirow{3}{*}{ Interval Nilai } & \multirow{3}{*}{ Kualifiksi } & \multicolumn{4}{|c|}{ MPBL + ICT } & \multicolumn{4}{|c|}{ MDI } \\
\hline & & \multicolumn{2}{|c|}{ Pretest } & \multicolumn{2}{|c|}{ Posttest } & \multicolumn{2}{|c|}{ Pretest } & \multicolumn{2}{|c|}{ Posttest } \\
\hline & & $f_{0}$ & $(\%)$ & $f_{0}$ & $(\%)$ & $f_{0}$ & $(\%)$ & $f_{0}$ & $(\%)$ \\
\hline$<40$ & Sangat kurang & 30 & 79 & 0 & 0 & 29 & 78 & 0 & 0 \\
\hline $40-54,99$ & Kurang & 7 & 18 & 1 & 3 & 8 & 22 & 4 & 11 \\
\hline $55-65,99$ & Cukup & 1 & 3 & 6 & 16 & 0 & 0 & 9 & 24 \\
\hline $66-79,99$ & Baik & 0 & 0 & 14 & 37 & 0 & 0 & 11 & 30 \\
\hline $80-100$ & Sangat baik & 0 & 0 & 12 & 45 & 0 & 0 & 13 & 35 \\
\hline \multicolumn{2}{|c|}{ Jumlah } & 38 & $100 \%$ & 38 & $100 \%$ & 37 & $100 \%$ & 37 & $100 \%$ \\
\hline \multicolumn{2}{|c|}{ Rata-rata } & \multicolumn{2}{|c|}{26,77} & \multicolumn{2}{|c|}{77,33} & \multicolumn{2}{|c|}{26,77} & \multicolumn{2}{|c|}{71,60} \\
\hline \multicolumn{2}{|c|}{ Standar Deviasi } & & 5,11 & \multicolumn{2}{|c|}{11,48} & &, 64 & \multicolumn{2}{|c|}{12,40} \\
\hline \multicolumn{2}{|c|}{$\begin{array}{c}\text { Rata-rata }<\mathrm{g}> \\
\text { Kualifikasi Gain Score }\end{array}$} & \multicolumn{4}{|c|}{$\begin{array}{l}0.69 \\
\text { Sedang }\end{array}$} & \multicolumn{4}{|c|}{$\begin{array}{l}0.61 \\
\text { Sedang }\end{array}$} \\
\hline
\end{tabular}

$\mathrm{f}_{0}$ : Frekuensi Observasi

Tabel 1 menunjukkan bahwa (1) nilai ratarata pretest pada kelas eksperimen dan kontrol relatif setara, (2) nilai rata-rata posttest pada kelas eksperimen lebih tinggi dibandingkan dengan kelas kontrol, karena memiliki selisih sebesar 5,73, (3) kelas eksperimen mengalami peningkatan keterampilan berpikir kritis yang lebih tinggi 
dibandingkan kelas kontrol. Hal tersebut dilihat dari nilai rata-rata $\mathrm{N}$-gain pada kelas eksperimen lebih tinggi dibandingkan kelas kontrol dan kedua kelas memiliki kualifikasi gain score yang sedang. Sebagai tindak lanjut dari hasil pretest dan posttest yang diperoleh, maka selanjutnya akan dilakukan analisis deskripsi terhadap jawaban siswa pada setiap dimensi keterampilan berpikir kritis. tujuannya adalah untuk mengetahui ketercapaian pada setiap dimensi keterampilan berpikir kritis.
Dimensi keterampilan berpikir kritis yang digunakan dalam menyusun tes adalah merumuskan maslaah, memberikan argument, melakukan induksi, melakukan deduksi, melakukan evaluasi dan memutuskan dan melaksanakan. Skor maksimal setiap butir per dimensi adalah 4 dan minimal adalah 0 . Skor yang diperoleh pada setiap dimensi keterampilan berpikir kritis siswa kemudian dianalisis menggunakan gain score ternormalisasi dan disajikan pada Tabel 2.

Tabel 2.

Profil Ketercapaian dimensi KBK

\begin{tabular}{lcccccccc}
\hline & \multicolumn{9}{c}{ Model Pembelajaran } \\
Dimensi & \multicolumn{9}{c}{ MPBL+ICT } & \multicolumn{4}{c}{ MDI } \\
KBK & Pre & Post & $<$ g $>$ & Kategori & Pre & Post & $<$ g $>$ & Kategori \\
\hline Dimensi I & 0,96 & 3,43 & 0,04 & Sedang & 0,96 & 3,51 & 0,04 & Sedang \\
Dimensi II & 1,07 & 2,91 & 0,03 & Sedang & 1,09 & 2,61 & 0,03 & Sedang \\
Dimensi III & 1,21 & 2,93 & 0,03 & Sedang & 1,22 & 2,49 & 0,02 & Sedang \\
Dimensi IV & 1,11 & 2,93 & 0,03 & Sedang & 1,16 & 2,85 & 0,03 & Sedang \\
Dimensi V & 1,07 & 2,92 & 0,03 & Sedang & 0,97 & 2,39 & 0,02 & Sedang \\
Dimensi VI & 1,10 & 2,91 & 0,03 & Sedang & 1,11 & 2,73 & 0,03 & Sedang \\
\hline
\end{tabular}

Tabel 2. Menunjukkan pada kelas eksperimen yang belajar dengan model Problem Based Learning berbantuan ICT ketercapaian dimensi keterampilan berpikir kritis yang paling tinggi berdasarkan hasil pretest adalah dimensi melakukan induksi dan yang paling rendah adalah dimensi merumuskan masalah. Sedangkan berdasarkan hasil posttest ketercapaian dimensi keterampilan berpikir kritis yang paling tinggi adalah dimensi merumuskan masalah dan yang paling rendah adalah dimensi memberikan argument dan memutuskan dan melaksanakan. Pada kelas kontrol yang belajar dengan model direct instruction ketercapaian dimensi keterampilan berpikir kritis yang paling tinggi berdasarkan hasil pretest adalah dimensi melakukan induksi dan yang paling rendah adalah dimensi merumumuskan masalah, sedangkan hasil posttest yang paling tinggi adalah dimensi merumuskan masalah dan yang paling rendah adalah dimensi melakukan evaluasi.
Nilai gain score $<\mathrm{g}>$ ternormalisasi terhadap ketercapaian dimensi keterampilan berpikir kritis siswa untuk kelompok PBL berbantuan ICT dan kelompok MDI disajikan pada grafik histogram Gambar 1.

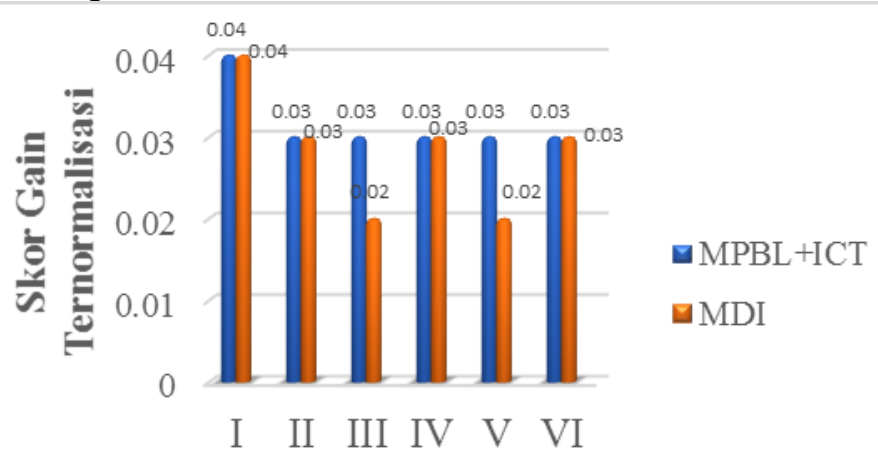

Dimensi Keterampilan Berpikir Kritis

Gambar 1.

Profil Ketercapaian Perdimensi Keterampilan Berpikir Kritis Siswa

Keterangan Dimensi:

Dimensi I : Merumuskan Masalah

Dimensi II : : Memberikan Argument 


$\begin{array}{ll}\text { Dimensi III } & \text { : Melakukan Induksi } \\ \text { Dimensi IV } & \text { : Melakukan Deduksi } \\ \text { Dimensi V } & \text { : Melakukan Evaluasi } \\ \text { Dimensi VI } & \text { : Memutuskan dan } \\ \text { Melaksanakannya. }\end{array}$

Hasil uji prasyarat menujukkan bahwa data penelitian berdistribusi normal ( $p$ $>0,05)$ untuk uji normalitas, uji homogenitas homogen $(p>0,05)$, memiliki arah regresi yang berarti dan berbentuk linier ( $p$ linearity $<0,05$; $p$ deviation from linearity $>0,05$ ). Berdasarkan hasil uji asumsi yang sudah dilakukan dapat disimpulkan bahwa data hasil penelitian telah memenuhi persyaratan sehingga uji hipotesis dengan Anakova dapat dilanjutkan. Hasil uji Anakova yang menunjukkan bahwa: (1) pengaruh pengetahuan awal siswa/hasil pretest terhadap keterampilan keterampilan berpikir kritis siswa/hasil posttest menunjukkan nilai statistik $p$ sebesar 0,000 dengan $p<0,05$. Hal ini menunjukkan bahwa terdapat pengaruh yang signifikan dari variabel kovariat, yaitu pengetahuan awal siswa terhadap keterampilan berpikir kritis. (2) setelah pengaruh kovariat, yaitu pengetahuan awal siswa dikendalikan secara statistik pengaruh model pembelajaran terhadap keterampilan berpikir kritis siswa menunjukan nilai $p$ sebesar 0,003 dengan $p<0,05$ sehingga keputusan yang dapat diambil adalah Ho ditolak. Hal ini berarti terdapat perbedaan keterampilan berpikir kritis antara siswa yang dibelajarkan dengan model pembelajaran problem based learning dan model pembelajaran direct instruction. Dengan demikian, perbedaan keterampilan berpikir kritis siswa dipengaruhi oleh model pembelajaran yang digunakan.

\section{PEMBAHASAN}

Pembahasan pada penelitian ini dibahas lebih lanjut mengenai hasil penelitian yang diperoleh dan pengujian hipotesis. Hasil penelitian tersebut meliputi analisis deskriptif dan Anakova yang mengungkap pengaruh variable bebas dan variable kovariat terhadap variable terikat. Variabel bebas dalam penelitian ini adalah model pembelajaran yang digunakan Variabel kovariat dalam penelitian ini adalah pengetahuan awal siswa dan variabel terikat dalam penelitian ini adalah keterampilan berpikir kritis siswa.
Pengetahuan awal siswa dilihat berdasarkan hasil pretest yang diberikan sebelum mendapatkan perlakuan. Hasil pretest tersebut menunjukkan bahwa, siswa pada kelas eksperimen nilai rata-rata 26,77 yang berada pada kualifikasi sangat kurang dengan standar deviasi 15,11. Sedangkan nilai rata-rata pretest siswa pada kelas kontrol adalah 26,77 yang berada pada kualifikasi sangat kurang dengan standar deviasi 14,64. Pengetahuan awal untuk kedua kelas dianggat setara. Pengetahuan awal yang dimiliki oleh siswa sangat penting dalam proses pembelajaran dan menjadi dasar dalam pencapaian keterampilan berpikir kritis siswa. Secara statistik hal tersebut dapat dibuktikan dengan hasil Anakova yang menunjukkan bahwa $\mathrm{p}<0,05$. Hasil ini menunjukkan bahwa terdapat pengaruh yang signifikan kovariat pengetahuan awal siswa terhadap pemahaman konsep IPA siswa. Siswa menggunakan pengetahuan awal untuk menginterpretasi ide-ide yang dipelajari dan mengkaitkannya dengan apa yang telah diketahui dan diyakini sebelumnya (Suastra,2009).

Setelah diberikan perlakuan pada kelas eksperimen dan kelas kontrol, siswa diberikan posttest untuk mengetahui keterampilan berpikir kritis siswa. Hasil posttest tersebut menunjukkan bahwa, siswa pada kelas eksperimen memiliki nilai rata-rata 77,33 yang berada pada kualifikasi baik dengan standar deviasi 11,48. Sedangkan nilai rata-rata posttest siswa pada kelas kontrol sebesar 71,60 yang berada pada kualifikasi baik dengan standar deviasi 12,40 . Nilai rata-rata posttest pada kelas eksperimen lebih tinggi dibandingkan dengan kelas kontrol dengan selisih sebesar 5,73.

Jika dikaitkan dengan hasil pretest, maka siswa pada kelas eksperimen memiliki peningkatan nilai rata-rata posttest terhadap pretest sebesar 50,56 dengan nilai rata-rata $\mathrm{N}$-gain sebesar 0,69 yang berada pada kualifikasi sedang, sedangkan kelas kontrol memiliki peningkatan nilai rata-rata posttest terhadap pretest sebesar 44,83 dengan nilai rata-rata $\mathrm{N}$-gain sebesar 0,61 yang berada pada kualifikasi sedang. Secara kuantitas peningkatan skor rata-rata kelas eksperimen lebih besar dibandingkan 
dengan siswa kelas kontrol. Hasil Anakova menunjukkan bahwa model pembelajaran berpengaruh terhadap keterampilan berpikir kritis siswa dengan nilai $p<0,05$ sehingga hipotesis nil (Ho) ditolak. Hal ini menunjukkan bahwa terdapat perbedaan keterampilan berpikir kritis siswa yang dibelajarkan dengan model pembelajaran problem based learning dan model pembelajaran direct instruction.

Perbedaan paradigma pembelajaran menjadi esensi fundamental dari masingmasing model pembelajaran yang digunakan. Perbedaan paradigma pembelajaran yang dimaksud adalah pandangan konstruktivisme pembelajaran dan pandangan behaviorisme pembelajaran. Esensi pandangan kontruktivisme adalah siswa mengkontruksi sendiri pengetahuannya melalui proses pembelajaran berdasarkan pengetahuan awalnya. Belajar dalam pandangan konstruktivisme bukanlah penambahan informasi baru secara sederhana, tetapi melibatkan interaksi antara pengetahuan baru dan pengetahuan yang telah dimiliki sebelumnya (Sadia, 2014). Model pembelajaran problem based learning merupakan salah satu model pembelajaran yang berlandaskan paradigma konstruktivisme. Problem Based Learning (PBL) merupakan suatu model pembelajaran yang berpusat pada siswa dan pembelajarannya dalam bentuk masalah nyata sehingga siswa mempunyai rasa ingin tahu yang kemudian siswa memecahkan masalah tersebut. Kelebihan model PBL terletak pada pemecahan masalah dalam pembelajaran sehingga hal tersebut dapat merangsang kemampuan kecakapan siswa. Salah satu dari kecakapan tersebut yaitu kemampuan berpikir kritis siswa pada sebuah konsep. Namun model PBL memerlukan waktu yang dalam pembelajaran sehingga guru sebagai fasilitator harus mempersiapkan pembelajaran secara maksimal. Model pembelajaran berbasis masalah (problem based learning) adalah suatu pendekatan pembelajaran yang menggunakan masalah dunia nyata sebagai suatu konteks bagi siswa untuk belajar tentang cara berpikir kritis dan kemampuan pemecahan masalah, serta untuk memperoleh pengetahuan dan konsep yang esensial dari materi pelajaran (Mahrani, 2017).

$$
\text { Barrows and Myers (1993) }
$$

menyatakan bahwa model pembelajaran problem based learning memiliki 5 langkahlangkah pembelajaran, diantaranya: (1) Starting A New Class, pada tahap ini guru menyampaikan tujuan pembelajaran dan apersepsi sebelum memulai pembelajaran. Pada tahap pertama ini guru meminta siswa untuk membentuk kelompok belajar untuk diskusi. (2) Starting New Problem, pada tahap ini guru membagikan LKS kepada masing-masing kelompok, guru menyampaikan msalah yang berkaitan dengan LKS yang sudah dibagikan. Penyampaian masalah ini dilakukan oleh guru, dimana guru memberikan suatu permaslahan kepada siswa untuk dipecahkan dengan memberikan siswa LKS yang dikerjakan oleh siswa dengan kelompoknya. Penyampaian masalah oleh guru ini dibantu dengan media ICT yang dapat berupa gambar, video, dan animasi atau simulasi yang ditayangkan didepan kelas dan diperhatikan oleh siswa untuk memecahkan suatu permaslahan. Guru meminta siswa untuk mengidentifikasi permasalahan yang ada dari mengajukan rumusan masalah, hipotesis, pengumpulan data, mensintesa informasi yang tersedia melalui kegiatan penemuan oleh siswa, merancang kegiatan/penyelidikan yang berkaitan dengan upaya pemecahan masalah. Tahapan ini berdampak pada ketercapaian indikator keterampilan berpikir kritis khususnya pada dimensi merumuskan masalah dan memberikan argument.

Tahap selanjutnya yaitu

Problem follow up, pada tahap ini siswa menggunakan berbagai sumber dan kemampuan berpikir kritis siswa, melakukan penyelidikan/eksperimen, dan menindaklanjuti pemecahan masalah. Tahapan ini berkaitan dengan indikator keterampilan berpikir kritis pada dimensi melakukan deduksi dan melakukan induksi (4) Performance Presentation, pada tahap ini masing-masing kelompok menyajikan pemecahan masalah didepan kelas dengan mempresentasikannya. Pada tahap keempat ini mengacu pada indikator keterampilan berpikir kritis dimensi melakukan evaluasi, (5) After conclusion of 
problem, pada tahap ini siswa memberikan kesimpulan terhadap hasil diskusi yang dilakukan di kelas. Tahapan kelima ini mengacu pada indikator keterampilan berpikir kritis pada dimensi melakukan induksi.

\section{Pandangan}

behaviorisme

memandang siswa sebagai komponen pasif dalam pembelajaran yang memerlukan motivasi luar dan dipengaruhi oleh penguatan/reinforcement yang diberikan oleh guru. Sudrajat (2011) Model pembelajaran direct instruction merupakan salah satu model pembelajaran yang berlandaskan paradigma behaviorisme. Model pembelajaran Direct Instruction adalah model pembelajaran yang menekankan pada penguasaan konsep atau perubahan perilaku dengan mengutamakan pendekatan deduktif.

Kardi \& Nur (2000) menyatakan bahwa model pembelajaran direct instruction memiliki 5 langkah-langkah pembelajaran, diantaranya: Menyampaikan tujuan dan kompotensi, pada tahap ini guru menjelaskan tujuan ini guru menjelaskan tujuan pokok pembelajaran, latar belakang pelajaran, pentingnya pelajaran, dan mempersiapkan siswa untuk belajar.

Mendemonstrasikan pengetahuan serta keterampilan, pada tahap ini guru mendemonstrasikan pengetahuan dan keterampialnnya yang benar dan memberikan informasi tahap demi tahap dan siswa mengamati dan mencermati demonstrasi guru serta mencatat hal yang penting. (3) Membimbing pelatihan, pada tahap ini guru membimbing dan memberikan pelatihan awal, siswa mengikuti pelatihan yang diberikan oleh guru pada tahap ini indikator keterampilan berpikir kritis yang dapat dicapai siswa adalah memutuskan dan melaksanakan. (4) Mengecek pemahaman dan memberikan umpan balik, pada tahap ini guru mengecek pemahaman siswa dengan memberikan umpan balik. Pada tahap ini indikator keterampilan berpikir kritis yang dicapai oleh siswa adalah memberikan argument. (5) Memberikan kesempatan untuk pelatihan lanjutan dan penerapan, pada tahapan ini guru memberikan latihan lanjutan yang lebih kompleks dalam kehidupan sehari-hari, siswa mengikuti pelatihan lanjutan. Pada tahap ini indikator keterampilan berpikir kritis yang dapat dicapai oleh siswa adalah melakukan evaluasi.

Perbedaan antara keterampilan berpikir kritis siswa pada kelompok MPBL dan kelompok MDI disebabkan karena pada model PBL siswa telebih dahulu diberikan permasalahan yang berkaitan dengan dunia nyata atau yang biasa dijumpai dalam kehidupan sehari-hari yang memiliki sifat ill-structured tanpa adanya bimbingan dari guru, dimana dalam hal ini siswa diminta agar lebih aktif dalam menyelesaikan permasalahan yang diberikan untuk melatih pola pikir siswa. Berkaitan dengan hal ini, Redhana (2012) Salah satu model pembelajaran yang menghadapkan siswa dengan masalah illstructured adalah model pembelajaran berbasis masalah. Pada model pembelajaran berbasis masalah, siswa pertama dihadapkan dengan masalah illstructured, open-ended, ambigu, dan kontekstual. Agar dapat memecahkan masalah, siswa harus mempelajari materi terlebih dahulu. Artinya, siswa harus mengkonstruksi pengetahuan melalui proses penemuan. Setelah siswa memahami materi yang terkait dengan masalah, siswa selanjutnya memecahkan masalah yang dihadapi. Dalam proses pemecahan masalah, siswa bekerja dalam kelompok. Masalah ill-structured ini dapat bertindak sebagai starting point untuk memulai pembelajaran dan sebagai motivator bagi siswa untuk mempelajari materi IPA. Berbeda halnya pada model Direct Instruction, siswa terlebih dahulu diajarkan oleh guru dimana guru langsung menjelaskan didepan kelas dan siswa memperhatikan sama halnya dengan guru berceramah dalam menyampaikan materi yang dibahas.

Nilai rata-rata keterampilan berpikir kritis pada kelompok siswa yang diberi perlakuan model Direct Instruction lebih rendah daripada kelompok siswa yang diberi perlakuan model PBL. Hal ini dikarenakan pada model DI siswa tidak diarahkan untuk merancang sendiri solusi penyelesaian masalah yang dihadapinya, siswa hanya langsung menjawab 
pertanyaan yang ada di LKS didiskusikan dengan anggota kelompoknya. Proses pembelajaran dengan metode ceramah dimana guru hanya menjelaskan saja didepan kelas bukanlah pembelajaran yang efektif, karena siswa tidak diberikan kesempatan untuk mengidentifikasi masalah dan menyelesaikan permasalahan yang ada di LKS dengan menggunakan pemikirannya sendiri. Siswa hanya mengerjakan LKS sesuai dengan rancangan yang telah disediakan pada LKS hanya menjawab pertanyaan saja. Hal inilah yang menyebabkan siswa menjadi malas dalam berpikir sehingga kegiatan diskusi siswa cendrung lebih lama karena siswa tidak mengerti apa yang harus dikerjakan. Selain itu, siswa yang malas cenderung hanya memanfaatkan teman sekelompoknya untuk mengerjakan LKS sehingga kontribusi seluruh siswa dalam proses pembelajaran tidak berlangsung optimal, sesuai dengan apa yang dialami oleh peneliti ketika kelas kontrol berdiskusi cendrung hanya satu siswa yang mengerjakan dan yang lainnya hanya melihat dan saling mengobrol dengan teman yang lainnya dan cendrung mengganggu kelompok lain. Pada saat presentasi juga banyak siswa yang tidak memperhatikan dan banyak siswa yang bercanda keluar masuk kelas. Selain itu, pembelajaran dengan model Direct Instruction tidak terdapat kegiatan yang mampu melatihkan keterampilan berpikir kritis siswa sehingga siswa tidak mampu mereflesikan solusi yang telah digunakan dalam menyelesaikan masalah yang dihadapinya. Berdasarkan pemamparan sebelumnya, model PBL berbantuan ICT ini lebih mampu dalam melatihkan keterampilan berpikir kritis siswa lebih baik dibandingkan dengan model Direct Instruction.

Hal ini terjadi karena siswa yang diajarkan dengan model PBL pengajarannya diawali dengan menghadapkan siswa kepada permasalahan yang berkaitan dengan kehidupan nyata dimana siswa menjadi lebih aktif selama proses pembelajaran berlangsung dalam menyelesaikan permasalahan tersebut yang mengasah pola pikir siswa agar menjadi lebih kritis sehingga dikatakan pembelajaran ini efektif dalam meningkatkan keterampilan berpikir kritis siswa. Sedangkan pada model DI siswa tidak dilatih dalam mengasah pola pikirnya siswa hanya diajarkan oleh guru dan guru yang menjelaskan didepan kelas seperti ceramah, sehingga pembelajaran dengan model ini sangatlah kurang efektif dalam hal meningkatkan keterampilan berpikir kirtis siswa.

Hasil penelitian ini sejalan dengan hasil-hasil penelitian sebelumnya yang relevan dengan penelitian ini. Hasil penelitian oleh Mahrani et al., (2017) yang menyatakan bahwa kemampuan berpikir kritis pada siswa yang menerapkan model pembelajaran problem based learning lebih baik daripada kemampuan berpikir kritis pada siswa dengan pembelajaran konvensional. Penelitian yang dilakukan oleh Arini (2016) yang menyatakan bahwa penerapan model problem based learning dapat meningkatkan kemampuan berpikir kritis dan kompetensi pengetahuan IPA.

Meskipun model pembelajaran problem based learning secara empiris dan teoritis lebih efektif dalam meningkatkan keterampilan berpikir kritis siswa dibandingkan dengan model pembelajaran direct instruction, namun secara deskriptif tidak semua siswa pada kelas eksperimen yang belajar dengan model pembelajaran problem based learning memiliki keterampilan berpikir kritis yang berkualitas sangat baik. Dari 38 siswa 3\% bekualifikasi kurang, 16\% berkualifikasi cukup, 14\% berkualifikasi baik dan $17 \%$ berkualifikasi sangat baik. Jadi model pembelajaran problem based learning belum mampu mengantarkan semua siswa pada pencapaian pemahaman konsep IPA dengan kualitas tinggi. Terdapat beberapa factor yang diduga mempengaruhi belum maksimalnya pencapaian keterampilan berpikir kritis siswa yang belajar dengan model pembelajaran problem based learning. Faktor-faktor yang dimaksud adalah sebagai berikut.

Pertama, siswa belum terbiasa belajar dengan menggunakan model pembelajaran problem based learning sehingga belum mampu mengikuti setiap tahapan pembelajaran dengan optimal. Kedua, siswa belum terbiasa dengan 
bentuk tes yang digunakan dalam penelitian ini.

\section{SIMPULAN DAN SARAN \\ SIMPULAN}

Berdasarkan hasil penelitian dan pembahasan, dapat disimpulkan bahwa terdapat perbedaan keterampilan berpikir kritis siswa yang dibelajarkan dengan model problem based learning berbantuan ICT dan model direct instruction $(\mathrm{p}=0,003$, $\mathrm{p}<0,05)$. Siswa yang dibelajarkan dengan model problem based learning berbantuan ICT memiliki nilai rata-rata 77,33 dengan kualifikasi baik dan kelompok kontrol yang dibelajarkan dengan model direct instruction memiliki nilai rata-rata 71,60 dengan kualifikasi baik.

\section{SARAN}

Berdasarkan hasil penelitian ini, maka dapat diajukan beberapa saran sebagai berikut.

a. Guru sains hendaknya memilih model pembelajaran yang cocok apabila ingin meningkatkan keterampilan berpikir kritis siswa. Salah satu alternatif model dan media yang dapat digunakan adalah model problem based learning (PBL) berbantuan ICT.

b. Sekolah hendaknya memperhatikan sarana maupun prasarana untuk siswa yang dapat menunjang proses pembelajaran.

c. Peneliti selanjutnya diharpkan melakukan penelitian lanjutan tentang upaya dalam meningkatkan keterampilan berpikir kritis siswa dengan memilih materi yang berbeda, menggunakan sampel yang lebih banyak dan design penelitian yang lebih tepat agar menghasilkan penelitian yang lebih baik.

\section{DAFTAR PUSTAKA}

Arini, S.A.K.D., Putra Semara, D.B.K.N., Suniasih, N.W. 2016. PENERAPAN MODEL Problem Based Learning Dapat Meningkatkan Kemampuan Berpikir Kritis Dan Kompetensi Pengetahuan Ipa. e-Journal PGSD Universitas Pendidikan Ganesha. Vol.4. No.1 (hlm.2). Tersedia Pada https://ejournal.undiksha.ac.id/index. php/JJPGSD/article/view/7080(diaks es pada 09 mei 2019)
Arsyad. 2007. Media Pembelajaran. Jakarta: PT RajaGralindo Persada.

Barrows. U.S. \& Myers.A.C. 1993. Problem Based Learning in Seconda Schoosl. Unpublished Monograph. Springtield. II: Problem Based Learning Institute. Lanphier High School and Southern Illionis University Medical School.

Fuad, N. M., Zubaidah, S., Mahanal, S., \& Suarsini, E. (2017). Improving junior high school critical thinking skills based on test three different models of learning. International Journal of Instruction. Vol.10, No.1. (hlm.102). Tersedia pada: https://files.eric.ed.gov/fulltext/EJ112 5163.pdf (diakses pada 09 November 2018

Iswandi Hazrul. 2016. Sekelumit Dari Hasil PISA 2015 Yang Baru Dirilis. Article online. Tersedia pada http:// www. ubaya.ac.id/2014/content/articles_d etail/230/Overview-of-the-PISA2015-results-that-have-just-beenReleased.html (diakses pada 10 mei 2019)

Kardi, S. \& Nur, M. 2000. Pengajaran Langsung. Surabaya: UNESAUniversity Press.

Mahrani, E., Bukit, N., Sinulingga, K. 2017. Efek Model Problem Based Learning Terhadap Kemampuan Pemecahan Masalah Dan Berpikir Kritis Pada Siswa Sekolah Menengah Pertama. Jurnal Pendidikan Fisika. 6(2) (hlm.81-86). Tersedia pada jurnal.unimed.ac.id /2012/index.php/ jpf/article/ download/8127/pdf (diakses pada 10 Mei 2019).

Nuryanti, L., Zubaidah, S., Diantoro, M. 2018. Analisis Kemampuan Berpikir Kritis Siswa SMP. Jurnal Pendidikan: Teori, Penelitian, dan Pengembangan. 2(3) (hlm.155-158). Tersedia pada: https: //www .resea rchgate.net/publication/ 325246731 (diakses pada tanggal 10 Januari 2019)

Nirbita, N.B., Joyoatmojo, S., Sudiyanto, S. 2018. ICT Media Assisted Problem Based Learning for Critical Thinking 
Ability. International Journal of Multicultural and Multireligious Understanding. Vol.5, No.2 (hlm.343). Tersedia pada : https://ijmmu.com/index.php/ijmmu/a rticle/view/295/194 (diakses pada tanggal 10 Mei 2019).

Niron, S.K. 2016. Pelaksanaan Pendekatan Saintifik Dalam Pembelajaran Di Kelas Iv Sd Negeri Nirmala Kabupaten Bantul. Jurnal Pendidikan Guru Sekolah Dasar Edisi 7 Tahun ke-5. (hlm.667) Tersedia pada :http://journal.student.uny.ac.id/ojs/oj s/index.php/pgsd/article/viewFile/12 45/1122 diakses pada tanggal 10 Mei 2019).

Pamungkas, A.S., \& Setiani.Y.2017. Peranan Pengetahuan Awal dan Self Esteem MatematisTerhadap Kemampuan Berpikir Logis Mahasiswa. Jurn al Matematika Kreatif-Inovatif. 8(1), (hlm.61-68). Tersediapada:https://journal.Unnes .ac.id/nju/index.

php/kreano/article/view/7866.(diakse s pada tanggal 10 Mei 2019).

Patonah, S. (2014). Elemen Bernalar Tujuan pada Pembelajaran IPA Melalui pendekatan Metakognitif Siswa SMP. Jurnal Pendidikan IPA Indonesia. 3(2) (hlm.128-133). Tersedia pada: http:// dx.doi. org/ 10.15294/ jpii.v3i2. 3111.(diakses pada tanggal 24 November 2018)

Prihartiningsih., Zubaidah, S., \& Kusairi. (2016). Kemampuan Berpikir Kritis Siswa SMP pada Materi Klasifikasi Makhluk Hidup. Prosiding Seminar Nasional Pendidikan IPA Pascasarjana UM, (1)1053-1062.

Redhana, I. W. 2012. Model Pembelajaran Berbasis Masalah dan Pertanyaan Socratik Untuk Meningkatkan Keterampilan Berpikir Kritis Siswa. FMIPA Universitas Pendidikan Ganesha. Cakrawala Pendidikan, November 2012, th. XXXI, no. 3. (hlm. 352-354) Tersedia pada http://journal.uny.ac.id/index.php/cp/ article/view/1136 (diakses pada tanggal 17 Desember 2017).
Retnosari, R., Susilo, H., Suwono, H. 2016. Studi Pendahuluan serta Kemampuan Awal Keterampilan Berpikir Kritis dan Berpikir Kreatif Siswa SMA Negeri Di Bojonegoro. Seminar Nasional Pendidikan dan Saintek 2016. Tersedia pada: https://publikasiilmiah.ums.ac.id/bitst ream/handle/11617/7984/95.pdf?se quence $=1$. (diakses pada 27 November 2018).

Rusman. 2012. Model-model Pembelajaran: Mengembangkan Profesionalisme Guru. Depok: PT Raja Grafindo Persada.

Sadia, I W. 2014. Model-Model Pembelajaran Sains Konstruktivisik. Yogyakarta: Graha IImu.

Sanjaya Wina. 2006. Strategi Pembelajaran Berorientasi Standar Proses Pendidikan. Jakarta. Kencana

Sarnapi. Peringkat Pendidikan Indonesia Masih Rendah. Artikel. 18 Juni 2016. Diakses pada tanggal $12 \mathrm{Juli}$ 2019. Tersedia pada: http: //www. pikiranrakyat.com/pendidikan/2016/ 06/18/peringkat-pendidikan-indone sia-masih -rendah-372187.

Setiawan, D. 2017. Pendekatan Saintifik Dan Penilaian Autentik Untuk Meningkatkan Mutu Pembelajaran Pendidikan Agama Islam. Journal of Basic Education. Vol.01, No.02 (hlm.38). Tersedia pada: http://journal.umpo.ac.id/index.php/a I-asasiyya/article/view/683 (diakses pada tanggal 24 November 2018

Suastra, I.W.2009. Pembelajaran Sains Terkini. Singaraja. Undiksha

Sudrajat, A. (2011). Model Pembelajaran Langsung. Tersedia pada: https:// akhmadsudrajat.wordpress.com/201 1/01/27/model-pembelajaran-la ngsung/ (diakses pada tanggal 08 Januari 2019)

Undang-Undang Republik Indonesia Nomor 20 Tahun 2003 Tentang Sistem Pendidikan Nasional : Tersedia pada

:https://kelembagaan.ristekdikti.go.id /wpcontent/uploads/2016/08/UU_no _20_th_2003.pdf 